\title{
Treatment of Water Using Water Hyacinth, Water Lettuce and Vetiver Grass - A Review
}

\author{
Piyush Gupta ${ }^{1, *}$, Surendra Roy ${ }^{1}$, Amit B. Mahindrakar ${ }^{2}$ \\ ${ }^{1}$ National Institute of Rock Mechanics, Kolar Gold Fields, India \\ ${ }^{2}$ Vellore Institute of Technology, Vellore, India
}

\begin{abstract}
Phytoremediation techniques for the treatment of different types of wastewater have been used by several researchers. These techniques are reported to be cost effective compared to other methods. Various contaminants like total suspended solids, dissolved solids, electrical conductivity, hardness, biochemical oxygen demand, chemical oxygen demand, dissolved oxygen, nitrogen, phosphorous, heavy metals, and other contaminants have been minimized using water hyacinth, water lettuce and vetiver grass. In this paper, role of these plant species, origin and their occurrence, ecological factors and their efficiency in reduction of different water contaminants have been presented.
\end{abstract}

Keywo rds Phytoremediation, Constructed Wetlands, Waste-Water Treatment, Water Hyacinth, Water Lettuce, Vetiver Grass

\section{Introduction}

Phytoremediation is one of the biological wastewater treatment methods[1], and is the concept of using plants-based systems and microbiological processes to eliminate contaminants in nature. The remediation techniques utilize specific planting arrangements, constructed wetlands (CW), floating-plant systems and numerous other configurations[2]. The removal of wastewater constituents are achieved by different mechanisms like sedimentation, filtration, chemical precipitation, adsorption, microbial interactions, and uptake of vegetation[3], among which, the most effective technology is phytoremediation strategy using CW technology. Besides water quality imp rovement and energy savings, CWs have other environmental protection features such as promoting biodiversity, providing habitat for wetland organis ms and wild life (e.g. birds and reptiles in large systems)[4], serving climatic (e.g. less $\mathrm{CO}_{2}$ production[4]; hydrological functions and biomethylation[5]). These systems are generally cost effective, simple, environmentally non-disruptive $[1,6]$ ecologically sound[7] with low maintenance cost[8] and low land requirements [9].

The principles of phytoremediation system are to clean up contaminated water, which include identification and implementation of efficient aquatic plant; uptake of

* Corresponding author:

piyush123123@gmail.com (Piyush Gupta)

Published online at http://journal.sapub.org/re

Copyright (C) 2012 Scientific \& Academic Publishing. All Rights Reserved dissolved nutrients and metals by the growing plants; and harvest and beneficial use of the plant biomass produced from the remediation system[9]. The most important factor in implementing phytoremediation is the selection of an appropriate plant $[1,10]$, which should have high uptake of both organic and inorganic pollutants, grow well in polluted water and easily controlled in quantitatively propagated dispersion[1]. The uptake and accumulation of pollutants vary from plant to plant and also from specie to specie within a genus[11]. The economic success of phytoremediation largely depends on photosynthetic activity and gro wth rate of plants [7], and with low to moderate a mount of pollution[12].

Many researchers have used different plant species like Water Hyacinth (Eichhornia crassipes (Mart.) Solms) [12-20], Water Lettuce (Pistia stratiotes L.) [21-25], Duckweed (Water Lemna), Bulrush (Typha), Vetiver Grass (Chrysopogon zizanioides) [1,26-28] and Common Reed (Phragmites Australis) for the treatment of water. They have used these species for different types of contaminated waters, effluents etc. Mkandawire and Dudel[29] have used duckweed and they found its growth was restricted above $34^{\circ} \mathrm{C}$ and $\mathrm{pH}$ sensitive. Mashauri et al.[30] used bulrush and his study revealed that the total dissolved solids (TDS) and electrical conductivity (EC) concentration was increased after treatment. Baskar et al.[31] in his study of kitchen wastewater treatment found only 4\% TDS removal by common reed. Hence water hyacinth, water lettuce and vetiver grass were selected for review because they efficiently removes the heavy metals and other pollutants with high reproduction rate, efficiency and tolerance of ecological factors. In this paper, role of these plant species have been discussed for the removal of water contaminants. 


\section{Role of Macrophytes in Water Contamination Removal}

Macrophytes play important roles in balancing lake ecosystem. For the first time, they were recognised during 1960s and 1970s in water quality improvement[32]. Aquatic macrophytes treatment systems for waste-water are the need of developing countries, because they are cheaper to construct and a little skill is required to operate[20]. They improve the water quality by absorbing nutrients with their effective root system[15]. Macrophytes not only retain nutrients by biomass uptake, but also increases sedimentation[33]. These are utilized for nutrient and metal removal from water in the forms of $\mathrm{CW}$ or retention ponds because of their fast growth rates, simple requirements, and ability to accumulate biogenic elements and toxic substances [9].

Aquatic plants are grouped into submerged, emergent, and floating-leaved based on their leaf's relation with water. During selection, biomass production, growth rate, and easiness of management and harvest should be taken into account[9]. Wetlands are mainly dominated by the floating aquatic macrophytes[34-36]. Floating aquatic plants can grow in vertical as well as horizontal direction, thereby increasing the photosynthetic surface area. These factors altogether makes floating aquatic plants, one of the earth's most productive communities [9]. The most common aquatic macrophytes among the floating-leaved, being employed in wastewater treatment are water hyacinth and water lettuce [37-39]. Impressive removal rates of inorganic nitrogen [nitrate $\left(\mathrm{NO}_{3}-\mathrm{N}\right)$, ammonium $\left(\mathrm{NH}_{4}-\mathrm{N}\right)$, and total $\left.\mathrm{N}\right)$ ] and phosphorus $\left(\mathrm{PO}_{4}-\mathrm{P}\right.$ and total $\left.\mathrm{P}\right)$ have been reported using aquatic plants especially when water hyacinth were utilized in nutrient or metal-rich wastewaters [9]. A wuah et al.[25] found $70 \%$ of TDS reductions by water lettuce. Vetiver can also be used as hydroponics. Hydroponics is cultivating the crops in nutrient solution or media without soil. Th is species is known for its wide capacity to adapt various water regime conditions, but probably its temperature requirements were not fully satisfied[10]. Ebrahim et al.[40] found that vetiver root can remove TDS in water about $55.93 \%$ by the adsorption method. In India, as there is plenty of abundant and agriculture based lands, therefore, these techniques for wastewater treatment can be used for safe disposal of contaminated water.

\section{Selected Plant Species for Treatment of Water}

\subsection{Water Hyacinth (Eichhornia crassipes (Mart.) Solms.)}

\subsubsection{Plant Origin and Geographical Distribution}

Water hyacinth is fast growing perennial aquatic macrophyte (requiring a wet habitat)[41] and prolific free floating aquatic weed[42]. It is a member of pickerelweed family - Pontederiaceae and Genus - Eichhornia. Its name Eichhornia was derived from well known 19th century Prussian politician J.A.F. Eichhorn[43]. This tropical plant spread throughout the world in late 19th and early 20th century[44]. According to Mitchell[45], the water hyacinth is indigenous to South America, particu larly to the Amazonian basin. It reached Australia in 1895, India in 1902, Malaysia in 1910, Zimbabwe in 1937 and the Republic of the Congo in 1952[46]. It is abundantly found in India, Bangladesh and South East Asia[47]. This plant is rounded, upright with shiny green leaves, lavender flowers [48] with dark blue root system[49,50].

It has the great reproduction potential as it grows double in 5 to 15 days $[14,16,49,51]$. Only ten plants in just eight months can produce population of 655,330 individuals [14]. It commonly forms dense, interlocking mats due to its rapid reproductive rate and complex root structure[52]. It reproduces both sexually and as exually[53]. It is available naturally in wide region over $33^{0} \mathrm{~N}$ to $33^{0} \mathrm{~S}$ of the equator and grow rapidly from $220 \mathrm{~kg} /$ ha-day to $600 \mathrm{~kg} / \mathrm{ha}$-day seasonally in pond with density from 224 to 412 tons/ha[54]. The inflorescence bears 6-10 lily-like flowers, each $4-7 \mathrm{~cm}$ in diameter[46] and the flowering period lasts for about fifteen days. When flowering cycle ends, flower stalk bends due to that spike reaches under the water surface and seeds are released directly into the water[14,55]. The height from flower top to root top of water hyacinth usually reach upto $1.5 \mathrm{~m}$ and more[56]. Arceivala [57] stated that individual plants ranges from 500 to $1175 \mathrm{~mm}$ from the top of the lavender flower to root tips.

\subsubsection{Ecological Factors}

For a phytoremediation system to work efficiently, optimal plant growth is the key parameter. Many environmental factors can influence plant growth and its performance, such as temperature, $\mathrm{pH}$, solar radiation, and salinity of the water. The weight and size of aquatic plants are a function of these factors. Its growth can be described by two ways: first by reporting the percentage of water surface covered for a period of time and second but more useful is by reporting the plant density in units of wet plant mass per unit of surface area[14,48]. Nutrient availability also affects the growth and performance of aquatic plants. As per Makhanu[58] it comprises of $95 \%$ water and 5\% dry matter, out of which silica, potassium, nitrogen and protein is $50 \%$, $30 \%, 15 \%$ and $5 \%$, respectively. It also provides breeding space and sanctuary for birds, fish, snails, insects and other wildlife[59]. Zhao et al.[60] found that nutrient concentration, mean nu mber of ra mets, mean height and total biomass of water hyacinth significantly increased with increasing nutrient level. Shorter time is required to reach maximum biomass yield in summer with high growth rate [61] whereas optimal water temperature for its growth is 28-30 ${ }^{\circ} \mathrm{C}$. Temperature above $33{ }^{\circ} \mathrm{C}$ inhibits further growth[55]. If temperature of $-3^{\circ} \mathrm{C}$ lasts for 12 hours, it will destroy all leaves and temperature of $-5^{\circ} \mathrm{C}$ for the period of 
48 hours will destroy whole plant[48]. Other researchers also found similar results about water hyacinth sensibility to low temperatures. According to Stephenson et al.[62], it can survive 24 hours at temperatures between 0.5 and $-5^{\circ} \mathrm{C}$ but it will die at -6 to $-7^{\circ} \mathrm{C}$ and cannot be grown in open where average winter temperature drops under $1{ }^{\circ} \mathrm{C}$. Therefore, it is not suitable for temperate or frigid areas due to their sensitivity to cool temperature [63]. Overall nutrient uptake is greater in summer when temperatures are higher and more favorable for plant growth[64]. Low air humidity from $15 \%$ to $40 \%$ can also be limiting factor for undisturbed growth of water hyacinth [65]. It tolerates drought as well because it can survive in moist sediments up to several months [55]. Generally, plant grows best in the $\mathrm{pH}$ range of 5.5-7.0[9]. Optimal water $\mathrm{pH}$ for $\mathrm{g}$ rowth of this aquatic plant is neutral but it can tolerate $\mathrm{pH}$ values from 4 to $10[66]$.

The growth rate of water hyacinth is strongly dependent upon the concentration of dissolved nitrogen $(\mathrm{N})$ and phosphorus $(\mathrm{P})$ in the water[67-69]. Sato and Kondo[70] reported that its maximu $m$ growth rate can be achieved at 28 $\mathrm{mg} / \mathrm{L}$ of total $\mathrm{N}$ and $7.7 \mathrm{mg} / \mathrm{L}$ of total $\mathrm{P}$. The levels of available nitrogen and phosphorus have often been cited as the most important factors in limiting water hyacinth growth[69,71-74]. According to Reddy et al.[69,71,72], 5.5 $\mathrm{mg}$ of $\mathrm{N} / \mathrm{L}$ and $1.06 \mathrm{mg}$ of $\mathrm{P} / \mathrm{L}$ is required for survival of water hyacinth growth whereas to achieve maximum growth $\mathrm{N}, \mathrm{P}$ and $\mathrm{K}$ (potassium) are added at the rate of $20 \mathrm{mg} \mathrm{N} / \mathrm{L}, 3$ $\mathrm{mg} \mathrm{P} / \mathrm{L}$ and $52 \mathrm{mg} \mathrm{K} / \mathrm{L}$, respectively. Therfore, to get the maximum growth usually $\mathrm{N}$ is added as ammonium nitrate, sodium phosphate as $\mathrm{P}$, and potassium chloride for K. Reddy and Tucker[75] suggested not only its nutrient concentration but also ratios between nutrients play an important role in plant growth. The highest production occurs when the N:P ratio in the water was close to 3.6. Plants need nitrogen for their metabolism to grow and to reproduce. According to Delgado et al.[76], water hyacinth prefers ammonium ions rather than nitrate ions. Water hyacinth absorbs ammonia by their roots to incorporate it in their biomass [31]. However, in the absence of ammonium $\mathrm{N}$, a high growth can also be achieved with nitrate as the only source of N[77]. Reddy et al.[71] suggests that the overall $P$ requirement of plant is very low in comparision of $\mathrm{N}$. Thinner and longer root enhance geometry for uptake of nutrients from the environment, hence $\mathrm{P}$ uptake depends on root length, diameter and surface area in contact with the environment[78]. Morphological plastic ity in root system is, thus favorable for water hyacinth to adapt to low-P environment[79]. Reddy et al.[72] stated that nitrogen content of hyacinth tissue is inversely related to the $\mathrm{K}$ supply rates. It has one of the highest $\mathrm{K}$ tissue concentrations when compared with other aquatic plants[80-81] which ranges from 10 to $83 \mathrm{mg}$ of $\mathrm{K} / \mathrm{g}$. Such a wide range of tissue K content sugges ts that it has high $\mathrm{K}$ requirement and a high $\mathrm{K}$ uptake capability[71]. Reddy et al.[72] found that maximum water hyacinth biomass $3.1 \mathrm{Kg}$ (dry weight) $/ \mathrm{m}^{2}$ at a concentration of $52 \mathrm{mg}$ of $\mathrm{K} / \mathrm{L}$. Knipling et al.[80] found maximu $\mathrm{m}, \mathrm{P}, \mathrm{K}$ concentration in the leaf, stem and root tis sue of water hyacinth, respectively.

The plant biomass (the sum of leaf, stem and root volumes) relates closely to evapotranspiration potential[82]. Over the years, some researchers have found evaporation from open water to exceed evapotranspiration of vegetated surfaces [83-85]. Water hyacinth evapotranspiration loss is in between 3 to 10 times $[54,86,87]$ in comparison of open water.

\subsubsection{Efficiency of Water Hyacinth In Reduction of Water Contaminants}

Information in the literature about plant yields and growth rates are varying. The productivity of water hyacinth cultured in nutrient enriched waters and wastewaters has been found to be in the range of 40-88 mt (dry wt) $/$ ha/yr[ $[88,89]$. Jo et al.[90] evaluated the growth of water hyacinth after 30 days and reported yield of $6402.5 \mathrm{~g} / \mathrm{m}^{2}$ whereas Sooknah and Wilkie[91] used hyacinth in dairy manure for 31 days and found its yield was $1608 \mathrm{~g} / \mathrm{m}^{2}$. DeBusk et a1.[92] evaluated hyacinth in secondarily treated municipal wastewater and reported plant productivity of 16 $\mathrm{g} / \mathrm{m}^{2} /$ day. Similarly, Ayyasamy et al.[93] observed biomass which increased from 75 to $101-106 \mathrm{mg} / \mathrm{L}$, with $37 \%$ increase in 10 days. Snow and Ghaly[94] found water hyacinth yields were 83 and $49 \mathrm{~g} / \mathrm{m}^{2}$ with hydraulic retention times (HRT) of 6 and 12 days, respectively. It has been estimated by Reed et al.[95] that 10 individual plants can spread and cover one acre pond within 8 months.

Richards[96] reported poor growth in distilled water because it produced small leaves with inflated petioles. According to Valipour et al.[18] water hyacinth is unable to survive in salinities above 2 ppt. Haller et al.[97] reported that it can withstand upto $2500 \mathrm{mg} / \mathrm{kg}$ (equivalent to 4040 $\mu \mathrm{S} / \mathrm{cm}$ ) and selenium concentration of more than $10 \mathrm{mg} / \mathrm{L}$ has phytotoxic effects on the water hyacinth [98].

The use of water hyacinth as the functional unit in wastewater treatment systems has been increasingly demonstrated and treatment regimens developed as a result of successful pilot projects $[35,99]$.

The water hyacinth has successfully resisted of its eradication by chemical, bio logical, mechanical, or hybrid means [100]. Adeniran[101] observed that the water hyacinth of CW based requires only $13 \%$ of the energy as co mpared to conventional sewage treatment plant for the same quantity of sewage and concluded that is a viable and cost effective option for the treatment of do mestic sewage in a developing economy. It has a huge potential for removal of the vast range of pollutants from wastewater[42,102-104] and has the ability to grow in severe polluted waters[105]. It is also used to improve the quality of water by reducing the levels of organic, inorganic nutrients[106] and heavy metals $[19,107-110]$. Presence of its fibrous root system and broad leaves help them to absorb higher concentrations of heavy metals[111]. It readily reduces the level of heavy metals in acid mine drainage water[112] and silver from industrial wastewater in short time[113]. Th is capability makes them a potential biological alternative to secondary and tertiary 
treatment for wastewater[35,114-116].

Water hyacinth has been found to stabilize temperature in experimental lagoons, thereby preventing stratification and increasing mixing within the water column[117]. Water hyacinth can convert alkaline $\mathrm{pH}$ into neutral[20,23]. The reduction in $\mathrm{pH}$ is due to absorption of nutrients or by simultaneous release of $\mathrm{H}+$ ions with the uptake of metal ions [20]. Borges et al.[118] obtained EC reduction by $18.1 \%$ in 5 days and TDS removal by $39.1 \%$ in 20 days. Lissy and Madhu[14] observed an increase in TDS when plant placed in the tank. Th is increase was due to the presence of clay or other fine particles present in the plant roots and or the presence of high $\mathrm{Cr}$ concentrations. On subsequent days, it showed that the TDS value considerably decreased by the accumulation process.

The reduction in $\mathrm{pH}$ favors microbial action to degrade biochemical oxygen demand (BOD) and chemical oxygen demand (COD) in the wastewater. According to Reddy[119], the presence of plants in wastewater depletes dissolved $\mathrm{CO}_{2}$ during the period of photosynthetic activity and an increase in DO of water, thus creates aerobic conditions in wastewater, which favors the aerobic bacterial activity to reduce the BOD and COD[20]. Dar et a1.[16] and Shah et al.[120] observed increase in DO level after using water hyacinth in wastewater whereas Mangas-Ramirez and Elias-Gutierrez [121] and Perna and Burrows[122] found lowered DO concentrations beneath the hyacinth mats. Trivedy and Pattanshetty[17] found that systems with shallow depth were more efficient in removing dissolved solids, suspended solids, BOD, COD, nitrogen and phosphorus. According to Valipour et al.[13] and Sooknah[123], higher pond depth can raise the anaerobic zones resulting slow organic degradation rate and foul odour emission. Many researchers $[93,124,125]$ have found that removal of nutrients is more efficient in young plants as compare to old; hence, regular harvesting of old plants is essential. If not harvested at an appropriate time, nutrients from the plants are leached back into the water and old plants after death cause anaerobic conditions in water[93]. Gamage and Yapa[126] used water hyacinth in textile mill and monitored for a period of one year. They observed BOD and COD removal was $75 \%$ and $81.4 \%$ respectively whereas Kulatillake and Yapa[127] reported $99 \%$ BOD and $80 \%$ COD removal for rubber factory effluents. Snow and Ghaly[94] found that the COD reductions decreased as HRT was increased and ammonium $\left(\mathrm{NH}_{4}\right)$ reductions were significantly affected by plant type, but were not significantly influenced by HRT. They also concluded that plant type and HRT both have significant effects on nitrate reductions. Koottatep and Polprasert[128] obtained $71.0 \%$ ( 1 day) and $83.0 \%$ (5 days) efficiency in COD reduction whereas Jing et al.[129] found 13.0 to $51.0 \%$ COD removal in river water. Mohamad[130] observed a rapid heavy metal uptake during first four days of contact time, and such uptake being decreased with time until it reached saturation.

Elias et al.[131] observed $87.0 \%$ efficiency in the reduction of ammonia, while as per Jing et al.[129], the efficiency in treating river water is $78.0-100.0 \%$. Koottatep and Polprasert[128] obtained 84.0-86.0\% removal efficiency of total nitrogen in 8 weeks of treatment; Schulz et al.[132] reported $19.0 \%$ efficiency in 14 days and $30.0 \%$ in 70 days whereas Cornwell et a1.[133] reported only $8.4 \%$ removal of nitrate-N in 10 months. Ingersoll and Baker[134] reported a removal efficiency of over $90 \%$ with an initial nitrate concentration of $30 \mathrm{mg} / \mathrm{L}$. For inorganic N, Reddy et al.[135] reported a reduction of about $80 \%$, while Sheffield[136] observed $94 \%$ inorganic $\mathrm{N}$ and $40-55 \%$ ortho-P reduction. For total P, Reddy et al.[135] measured about $32 \%$ reduction, while Ornes and Sutton[137] achieved a higher removal rate of $80 \%$. Bramwell and Devi Prasad[138] observed during a pilot scale study an average decrease in total $\mathrm{N}$ and total $\mathrm{P}$ by $27.6 \%$ and $4.48 \%$, respectively. Sheffield [136] reported that pond with an air stripping unit, a flocculation and settling unit, removes $>99 \%$ ortho-P, $99 \%$ nitrate, and $>99 \%$ ammonia. According to Knipling et al.[80], harvesting of one acre of hyacinth would remove $170 \mathrm{~kg}$ of N and $60 \mathrm{~kg}$ of $\mathrm{P}$ and in maximum growth, one hectare of hyacinths could remove about $2500 \mathrm{~kg}$ of N/yr[139] and as high as $7629 \mathrm{~kg}$ of N/ha/yr[75]. According to Ayyasamy et al.[93], nitrate removal efficiency of water hyacinth was increased to 64 , 80 and $83 \%$ with in itial nitrate concentrations of 100,200 and $300 \mathrm{mg} / \mathrm{L}$, respectively, but it is decreased with 400 and $500 \mathrm{mg} / \mathrm{L}$. This was due to osmotic pressure at higher concentrations not supporting the uptake of nitrate[140]. In the ground water samples, the nitrate removal was greatly dependent upon the presence of other nutrients, such as sulphate and phosphate, which caused lower nitrate uptake by water hyacinth [93].

Gamage and Yapa[126] used hyacinth in textile effluent and found reductions in volatile solids $(72.6 \%)$, mean suspended solids $(46.6 \%)$, phosphate $(52.9 \%)$, sodium ( $40.2 \%$ ), potassium $(64.4 \%)$, dissolved solids $(61.07 \%)$, total solids $(59.4 \%)$, total nitrogen $(83.5 \%)$ and chloride reduction $(36.0 \%)$. An increase in nitrate ion concentration was observed, suggesting nitrification of organic nitrogen in the medium during the long HRT of 30 days. $\mathrm{pH}$ varied from 12.8 to 7.0 at inlet and after treatment it was in between 8.52 to 6.50 , whereas John[141] observed $\mathrm{pH}$ levels were increased by water hyacinth irrespective of different effluents with HRT's.

Mane et al.[98] indicated that at lower concentrations (5 $\mathrm{mg} / \mathrm{L}$ ) of heavy metals, the plant growth was normal and removal efficiency was greater. Concentrations greater than $10 \mathrm{mg} / \mathrm{L}$, the plant started wilting and removal efficiency was reduced due to toxicity at higher metal concentrations. O'Keefe et al.[142] found similar nature of metal uptake for cadmiu $\mathrm{m}$. Water hyacinth without reduction in growth have high removal rates for iron $(\mathrm{Fe})$, zinc $(\mathrm{Zn})$, copper $(\mathrm{Cu})$, chromium $(\mathrm{Cr})$, cad mium $(\mathrm{Cd})$, manganese $(\mathrm{Mn})$, nickel $(\mathrm{Ni})$, mercury (Hg) and arsenic (As)[143-146]] from aqueous solutions besides absorbing organic substances such as phenol, formaldehyde, formic, acetic and oxalic acids [144-146]. Liao and Chang[146] found that the absorption capacity for water hyacinth, as $0.24 \mathrm{~kg} / \mathrm{ha}$ for $\mathrm{Cd}, 5.42 \mathrm{~kg} / \mathrm{ha}$ 
for lead $(\mathrm{Pb}), 21.62 \mathrm{~kg} / \mathrm{ha}$ for $\mathrm{Cu}, 26.17 \mathrm{~kg} / \mathrm{ha}$ for $\mathrm{Zn}$, and $13.46 \mathrm{~kg} / \mathrm{ha}$ for Ni. Valipour et al.[18] stated that if heavy metals exceed the saturation limit of 268 and $2152 \mathrm{mg} / \mathrm{kg}$ for $\mathrm{Cd}, 381$ and $3372 \mathrm{mg} / \mathrm{kg}$ for $\mathrm{Cu}, 229$ and $1850 \mathrm{mg} / \mathrm{kg}$ for Ni, 462 and $2764 \mathrm{mg} / \mathrm{kg}$ for $\mathrm{Zn}$ in shoots and roots, respectively, it can lead to mo rphological deformity. It is the best species as $\mathrm{Cd}$ accumulators[110,147,148]. In California, water hyacinth leaf tissue was found to have the same mercury concentration as the sediment beneath, suggesting that plant harvesting could help mediate mercury contamination if disposed of properly[149]. Mishra et al.[111] used hyacinth for coal min ing effluent for the removal of heavy metals and observed 70.5 $\pm 4.4,69.1 \pm 3.9,76.9 \pm 1.4,66.4 \pm 3.45,65.3$ \pm 2.4 and $55.4 \pm 2.9$ percent $\mathrm{Fe}, \mathrm{Cr}, \mathrm{Cu}, \mathrm{Cd}, \mathrm{Zn}$ and $\mathrm{Ni}$, respectively was removed. The study revealed that plant roots accumulates heavy metals approximately 10 times of its initial concentration whereas Chandra and Kulshreshtha [150] reported 18.92 (g dry tissue wt) Cr accumulation in roots of water hyacinth.

According to Lindsey and Hirt[151], water hyacinth can be used like food for people or fodder because its leaves are rich in proteins and vitamin $\mathrm{A}$. But it is not recommended to consume if used for removal of heavy metals and toxic substances as it can cause problems when enter in food chain[102]. Its biomass is rich in nitrogen and other essential nutrients. Apart from biogas[152], its sludge contains almost all nutrients and can be used as a good fertilizer with no detrimental effects on the environ ment[51]. After harvesting, it can be used for composting, anaerobic digestion for production of methane, fermentation of sugars into alcohol [48], green fertilizer, compost and ash in regenerating degraded soils. These operations can help in recovering expenses of wastewater treatment.

\subsection{Water Lettuce (Pistia Stratiotes $L$.)}

\subsubsection{Plant Origin and Geographical Distribution}

Pistia stratiotes (L.) is a floating perennial commonly called water lettuce belonging to the family Araceae. It floats on the surface of the water, and its roots hanging submerged beneath floating leaves[23]. While it may have orig inated in South America but the origin of water lettuce is uncertain. It has been used in Africa as a medicine and fodder for cattle for centuries being recorded in Egypt in 77 A.D.[153]. It has spread over the rest of Africa and parts of Asia and in the 1970s also found its way to Australia[154]. The leaves can be up to $14 \mathrm{~cm}$ long and have no stem. They are light green, with parallel veins, wavy margins and are covered in short hairs which form basket-like structures and help in trapping air bubbles, increasing the plant's buoyancy. The flowers are dioecious and are hidden in the middle of the plant among the leaves. The plant can be reproduced by both vegetatively and sexually $[23,155]$.

Water Lettuce is non winter-hard plant, having a minimum growth at temperature $15^{\circ} \mathrm{C}[156]$. In general, the specific growth rate of water lettuce is slightly higher as compared to the water hyacinth in dry season. However, the rainy spell reduces the growth of the water lettuce because of the lower solar rad iation, which is needed for its growth[157]. Fonkou et al.[21] stated that lettuce doubles its biomass in just over 5 days; triples it in 10 days, quadruples in 20 days and has its original bio mass multip lied by a factor of 9 in less than one month. This evolution indicates that 25 days is the maximum period to allow the plant in the system. Because this plant reproduces rapidly and decays, the efficacy of the system is intimately linked to its careful management trough periodic harvesting of part of the bio mass produced.

Especially in tropical or subtropical areas, water lettuce (large-leaved floating plant) is used in phytoremediation water systems [158-159]. Th is is because, compared to native plants, this invasive plant show a much higher nutrient removal efficiency with their high nutrient uptake capacity, fast growth rate, and big biomass production[41].

\subsubsection{Ecological Factors}

Water lettuce is superior in productivity as compared to other small aquatic weeds such as Lemna spp[61]. Knowledge on salinity tolerance of plant can help better utilize the plant(s) without bringing disaster because it has significant effects on growth and performance. According to Haller et al.[97], floating plants such as water lettuce have higher survival rate, at higher levels of EC having a killing strength $(>4000 \mu \mathrm{S} / \mathrm{cm})$. This indicates that water lettuce withstand higher salinity conditions but does not grow at higher COD levels [91].

Although water lettuce can produce high biomass and remove large amounts of nutrients and metals, they may not be suitable for temperate or frigid areas due to their sensitivity to cool temperature which significantly affects their performance[63]. Lu[9] suggested that $\mathrm{Fe}, \mathrm{Cu}$, and $\mathrm{Ni}$ are essential for plant growth, but when present at high concentrations, they are toxic to plant. Lu et al.[22] also reported that low concentration of nutrients may reduce the performance of plant in removing nutrients.

\subsubsection{Efficiency of Water Lettuce in Reduction of Water Contaminants}

Plants are known to accumulate large quantities of nutrients during period of rapid growth[160]. Fonkou et al.[21] observed in 25 days, the b io mass increased in 7 ponds from the original $518 \mathrm{~g} / \mathrm{m}^{2}$ (average) to $2488,2578,2925$, $5379,6176,6793 \mathrm{~g} / \mathrm{m}^{2}$ respectively whereas Ayyasamy et al.[93] observed during the 10 day experiments, the biomass of water lettuce increased from 75 to $92-94 \mathrm{mg} / \mathrm{L}$ with $24 \%$ increases. Water lettuce of $1.25 \mathrm{mg} \mathrm{N} / \mathrm{L}$ treatment doubled its initial b io mass. Plant showed healthy bright green without yellowing of the old leaves. Lower $\mathrm{N}$ and $\mathrm{P}$ requirements make water lettuce desirable for a polyculture system. The N, $\mathrm{P}$ and ash contents of biomass were about 1.5 times lesser in water lettuce than in water hyacinths[161]. A 200- fold difference in dry weight of water lettuce was reported by Aoi and Hayashi[161] between cultivated in rain water and 
treated sewage water. Fonkou et a1.[21] indicated that the number of leaves per plant decreases, as a result of the decay of the basal leaves that fall back into water, then releasing the substances that were absorbed after 15 days in all the treatment ponds. It was found that EC, DO and ammonia are poorly removed. Unpublished works reported total bacteria, faecal Streptococci and Salmonella sp. to be fairly eliminated in the system by $52.7-64.3 \%, 45.6-79.5$ and $35.5-66.4 \%$ respectively. DO was increased from 0.75 to 6.02 with imp rovement of $87.5 \%$.

Dipu et al.[23] found that alkaline $\mathrm{pH}$ was changed into neutral using lettuce. Similar results were also reported by Mahmood et al.[20]. The reduction in $\mathrm{pH}$ is due to absorption of nutrients and other salts by plants or by simultaneous release of $\mathrm{H}+$ ions with the uptake of metal ions[20]. Awuah et al.[25] used lettuce in their study of bench-scale continuous-flow wastewater treatment system with feed of sewage. They observed that lettuce removed TDS by $70 \%$, fecal coliform by $99 \%$, BOD by $93 \%$, COD by $59 \%$, nitrate by $70 \%$, total phosphorus by $33 \%$ and ammonia by $95 \%$. Water lettuce is reported to reduce the ammonium ions from the water as it utilizes ammonium $\left(\mathrm{NH}_{4}-\mathrm{N}\right)$ prior to nitrate $\left(\mathrm{NO}_{3}-\mathrm{N}\right)$ as nitrogen source and does not switch on the utilization of $\mathrm{NO}_{3}-\mathrm{N}$ until $\mathrm{NH}_{4}-\mathrm{N}$ gets consumed entirely[161]. Ingersoll and Baker[134] reported nitrate removal efficiency of water lettuce ranged from 31 to $51 \%$. However, according to Aoi and Hayashi[161], at an initial nitrate concentration of $5.5 \mathrm{mg} / \mathrm{L}$, water lettuce had a similar nitrate removal capacity to water hyacinth in batch culture experiments[93]. It has been extensively used to remove metals like $\mathrm{Zn}, \mathrm{Ni}$, and $\mathrm{Cd}$ from the water column[162]. However, at $20 \mathrm{mg} / \mathrm{L} \mathrm{Cr}$, plants of lettuce showed $100 \%$ death after three days[163].

Preliminary study by $\mathrm{Lu}[9]$ revealed that water lettuce growth decreased the EC in the treatment plot due to salt removal from the waters by plant uptake or root adsorption and it was concluded that water quality in ponds was improved by phytoremediation with water lettuce, as evidenced by decreased turbidity, total solids, $\mathrm{NH}_{4}-\mathrm{N}$, $\mathrm{NO}_{3}-\mathrm{N}$ and total Kjeldahl $\mathrm{N}$, and nutrient concentrations. Reductions in ortho $\mathrm{P}$, total dissolved $\mathrm{P}$, and total $\mathrm{P}$ concentrations was found by $18-58 \%$ compared to the control plots. Metals were substantially accumulated in the roots of water lettuce. A larger proportion of $\mathrm{Ca}, \mathrm{Cd}, \mathrm{Co}, \mathrm{Fe}$, $\mathrm{K}, \mathrm{Mg}, \mathrm{Mn}$, and $\mathrm{Zn}$ were attached to external root surfaces by adsorption or surface deposition while more $\mathrm{Al}, \mathrm{Cr}, \mathrm{Cu}, \mathrm{Ni}$, and $\mathrm{Pb}$ were absorbed and accumulated into the roots.

A study conducted by $\mathrm{Lu}$ et al.[22] indicated that total suspended solids in the water column were decreased by approximately $10 \%$ in treatment plots compared to control plots. Water lettuce growth decreased water $\mathrm{pH}$, which was not expected for it is well known fact that water $\mathrm{pH}$ rises with plant photosynthesis. Besides plant uptake, denitrification may also contributed to the decreased $\mathrm{NO}_{3}-\mathrm{N}$ concentration in the treatment plots as a more anaerobic condition (dissolved oxygen $<1.5$ ) which was created by the growing plants at the water's surface and other anaerobic micro-sites $[164,165]$. Aluminiun (Al), calcium (Ca), Fe, K, and $\mathrm{Mn}$ concentrations in the remediation plots were significantly $(\mathrm{P}<0.01)$ reduced by the growth of water lettuce. Water lettuce can be considered a hyperaccumu lator for trace metals such as $\mathrm{Cr}, \mathrm{Cu}, \mathrm{Fe}, \mathrm{Mn}, \mathrm{Ni}, \mathrm{Pb}$, and $\mathrm{Zn}[166]$. Periodic harvesting of water lettuce is necessary not only for maintaining an optimal growth density, but also for effective removal of nutrients ( $\mathrm{N}$ and $\mathrm{P}$ ) and metals from the waters, otherwise the nutrients and metals would be released back into the water system after the plant died and decomposed[21,166].

Mukhopadhyay et al.[167] found that the removal is dependent both on the contact time and the initial arsenic concentration. He observed a rapid initial uptake upto 48 hours and gradual attainment of equilibriu m after 120 hours. Such concentration and duration dependent removal were also obtained for cadmium using water hyacinth[142] and water lettuce[168] and for $\mathrm{Hg}$ (II) using lettuce[169]. According to Mukhopadhyay et al.[167] and O'Keefe et al.[142], metal uptake was higher for low metal concentration and decreased thereafter with increase in metal concentration. Some researchers found similar nature of metal uptake in water lettuce for cadmium and for arsenic. Mishra et al.[170] found water lettuce removed $80 \%$ of mercury (i.e. from $10 \mu \mathrm{g} / \mathrm{L}$ to $2 \mu \mathrm{g} / \mathrm{L}$ ) from the coal mining effluent in 21 days. Mercury accumulation in the roots of lettuce was about four times higher than the shoots at lower concentrations[111,143,171,172]. Maine et al.[42] found water lettuce efficiently removed $\mathrm{Cr}$ from water at the concentrations of $1,2,4$, and $6 \mathrm{mg} \mathrm{Cr} / \mathrm{L}$.

\subsection{Vetiver Grass (Vetiveria Zizanioi des L.)}

\subsubsection{Plant Origin and Geographical Distribution}

Vetiver grass (Chrysopogon zizanioides) belongs to the Gramineae family. The vetiver is a unique tropical plant that has been proven and used in some 100 countries for soil and water conservation, land rehabilitation, pollution control, water quality improvement and many other environmental applications, particularly the looming food crisis in many parts of the developing world. The vetiver System is easy to use and low cost[173,174]. It is tall erect and native to India, South and South-East Asia[175]. It is found throughout the plains, lower hills of India particularly on the riverbanks, in marshy soils and it is widely used in Karnataka, India[27]. It is an herbaceous perennial plant, the leaves are erected and rather stiff with height ranges from 0.5 to $1.5 \mathrm{~m}$. It has a deep and resistant root system with fast growth[10]. According to Dulton et a1.[176], it is characterized by its large bio mass and having a dense root system extending up to $3 \mathrm{~m}$ in depth. It has fine purple flowers and an architectural aesthetic that can be well incorporated in landscape designs[173].

Vetiver system is based on the use of vetiver grass, which was first recognized early in the 1990s for having "super absorbent" characteristics suitable for the treatment of wastewater and leachate generated from landfill[177]. 


\subsubsection{Eco logical Factors}

Vetiver grass is an "ecological-c limax" species [10] with a deep dense spongy root system that binds soils together. Vetiver can withstand drought $[28,178]$ and is not affected by flood[178]. A though vetiver is a tropical grass[179] can also tolerate extreme temperatures, from $-15{ }^{\circ} \mathrm{C}$ to $60{ }^{\circ} \mathrm{C}[28]$. According to Zhang[180], it grows rapidly above $25^{\circ} \mathrm{C}$. Many researchers have used vetiver for extreme cold conditions like in Australia, vetiver gro wth was not affected by severe frost at $-11^{\circ} \mathrm{C}$ and it survived for a short period at $-22^{\circ} \mathrm{C}$ in northern China. In Georgia (US), vetiver survived in soil temperature of $-10^{\circ} \mathrm{C}$ but not at $-15^{\circ} \mathrm{C}[181]$ whereas Maffei[178] records vetiver having an absolute minimum temperature of $-15^{\circ} \mathrm{C}$ below which death occurred. Vieritz et al.[179] reported that although very little shoot growth occurred at the soil temperature range of $15{ }^{\circ} \mathrm{C}$ (day) and $13{ }^{\circ} \mathrm{C}$ (night), root growth continued at the rate of 126 $\mathrm{mm} /$ day, indicating that vetiver grass was not dormant at this temperature. It was concluded that under frosty weather, its top growth is killed but its underground growing points survived, plants grow more slowly under colder conditions and the growth stages are better defined on the basis of thermal time rather than chronological time. Maffei[178] describes vetiver as growing luxuriantly in areas with temperatures ranging from $21-45{ }^{\circ} \mathrm{C}$. According to Maffei[178] and Zhang[180] root length, root and shoot dry weight increased with increasing temperature from $15 / 13$ to $35 / 30{ }^{\circ} \mathrm{C}$ (day/night) and minimum daily air temperature for growth should be less than $12^{\circ} \mathrm{C}$.

Even though it is not an aquatic plant, vetiver can be established and survive under hydroponic conditions. However, vetiver cannot be established directly in leachate ponds, as it does not float as alligator weed (Alternanthera philoxeroides); it needs a floating platform to grow on. Its high affinity for both organic and inorganic chemicals shows that the grass could be used to develop a cost effective and environment friendly remediation for waste water[28]. Xia et al.[182] suggested that for sustainable removal of pollutants from leachates, vetiver shoots should be trimmed 2-3 times per year.

\subsubsection{Efficiency of Vetiver Grass in Reduction of Water Contaminants}

Vetiver grows rapid ly and has a huge biomass [182]. It can purify eutrophic water[183], garbage leachates[182] and wastewater from pig farms[184]. It is excellent for the removal of heavy metals from contaminated soil[ $[185,186]$ and rehabilitating landfills[187]. It has proven to be exceptionally successful in urban environments by demonstrating its ability to absorb pollutants into its foliage[173]. According to Xia et al.[182], vetiver has high level of tolerance for polluted water and very effective in removing pollutant from landfill leachates, particularly $\mathrm{N}$ and P. Nitrogen and Phosphorus absorption is also expedited because roots have direct exposure to effluents. It tolerates wide range of $\mathrm{pH}$, salinity, sodicity[175,188], acidity and heavy metals such as $\mathrm{As}, \mathrm{Cd}, \mathrm{Cu}, \mathrm{Pb}$ and $\mathrm{Zn}[188]$ It could also absorb higher N, P and K[196]. Jayashree et al.[189] used this system upto 60 days for the treatment of textile water and found that $\mathrm{pH}$ reduced from 8.6 to 7.8 , EC from 1.34 to $0.22 \mathrm{dS} / \mathrm{m}$, total kjeldahl nitrogen from $8.85 \%$ to $0.53 \%$, P from $5.9 \%$ to $0.81 \%$. Researchers $[178,188]$ found that it has high level of tolerance to salin ity.

Vetiver can be used in phytoremediation of contaminated water system and has been reported to adsorb many heavy metals [187]. Ho wever, the concentration of heavy metals in wastewater played an important role in vetiver growth. The vetiver ecotypes absorbed $\mathrm{Fe}>\mathrm{Mn}>\mathrm{Zn}>\mathrm{Cu}>\mathrm{Pb}$, and they concentrated these metals more in roots than in shoots[1]. It has been used successfully for contaminants removal in many countries such as Australia, China, Thailand, Vietnam and Senegal[181]. Truong et al.[175], soils that can even be loaded with very high levels of aluminium $(>68 \mathrm{Al} /$ cation exchange capacity \%), iron, manganese ( $>578 \mathrm{ppm})$ and other heavy metals often associated with acidic soils such as $\mathrm{As}, \mathrm{Cd}, \mathrm{Cu}, \mathrm{Cr}$ and $\mathrm{Ni}$. It can also withstand high levels of pesticides and herbicides and also to a wide range of toxics[10].

Girija et a1.[28] stated that the higher temperature favors their growth and multiplication. Low values of $\mathrm{pH}$ become almost neutral after one month of its planting. EC of polluted water is directly proportional to its dissolved mineral matter content and after planting vetiver, the EC decreased to a very low value. Lakshmana et al.[27] also found the same result. Hardness was found to be ranging from 106-206 mg/L but after planting vetiver, a $60 \%$ removal was observed in 2 months, which is in agreement with Truong and Hart[190]. DO was increased from 0 to $4.5 \mathrm{mg} / \mathrm{L}$ after 1 month which is in agreement with Stefanie et al.[191]. With an increase in $\mathrm{EC}$, coliforms too increased in number. DO have an inverse relationship with the coliform and is directly proportional to $\mathrm{COD}$ and BOD. As the organic matter is the food of coliform bacteria, Boonsong and Chansiri[192] observed higher BOD and COD removal efficiency.

Mane et al.[98] found that shoot length of vetiver grass was increased by $18.6 \%$ at $200 \mathrm{mM} \mathrm{NaCl}$ concentration whereas; increase in root length about $24.8 \%$ was observed at $50 \mathrm{mM} \mathrm{NaCl}$. The average leaf area also increased under saline conditions. Dry weight and fresh weight bio mass was less effective under salinity stress. They also observed increased levels of polyphenols at elevated salin ity due to the accumulation of secondary metabolites. Linear increase in the EC and TDS of the soil was found at increasing salinity and the vetiver is tolerant upto $100 \mathrm{mM}$ of salinity because of increase in growth and photosynthetic parameter. Ebrahim et al.[40] indicated decrease of TDS by $55.93 \%$ in hard water with the help of vetiver root by using adsorption method.

Department of Natural Resources and Mines, Queensland research showed that vetiver grass has a fast and very high capacity for absorption of nutrients, particularly nitrogen and phosphorus in wastewater[26,193]. Wagner et al.[194] found that both $\mathrm{N}$ and $\mathrm{P}$ supplies increased vetiver growth significantly $(<1 \%$ level $)$. Gro wth increased mainly with the 
level of $\mathrm{N}$ supplied. However, very little growth response occurred at rates higher than $6000 \mathrm{~kg} / \mathrm{ha} /$ year although rates up to $10,000 \mathrm{~kg} / \mathrm{ha}$ of $\mathrm{N}$ did not adversely affect vetiver growth. Vetiver requirement for $\mathrm{P}$ was not as high as for $\mathrm{N}$, and no growth response occurred at rates higher than 250 $\mathrm{kg} / \mathrm{ha} /$ year. However, its growth was not adversely affected at $\mathrm{P}$ up to $1000 \mathrm{~kg} / \mathrm{ha} /$ year. Anon[195] and Zheng et al.[196] found $98 \%$ removal for total $\mathrm{P}$ in 4 weeks and $74 \%$ for total $\mathrm{N}$ after 5 weeks in polluted river water. Wagner et al.[194] used vetiver in hydroponic system using sewage effluent and observed that both $\mathrm{N}$ and P removal over $90 \%$ from the effluent; it also reduced algae growth and faecal coliforms. Truong and Hart[190] used vetiver for domestic effluent treatment for 4 days and the removal in total nitrogen was $94 \%$, total $\mathrm{P}$ was $90 \%$, EC by $50 \%$, change in $\mathrm{pH}$ was (from 7.26 to 5.98 ), faecal coliform changes were $44 \%$ and E. coli changes were $91 \%$. Therefore, vetiver has high potential to be used for industrial wastewater treatment.

\section{Concluding Remarks}

It has been observed that phytoremediation of wastewater using the floating plant system is a predominant method which is economic to construct, requires little maintenance and increase the biodiversity. Many researchers have used water hyacinth, water lettuce and vetiver grass for the removal of water contaminants but their treatment capabilities depend on different factors like climate, contaminants of different concentrations, temperature, etc. Vetiver grass can be grown as floating in water without the soil media (hydroponic way). The removal efficiency of contaminants like TSS, TDS, BOD, COD, EC, hardness, heavy metals, etc varies from plant to plant. Plant growth rate and hydraulic retention time can influence the reduction of contaminants. Therefore, an available knowledge and techniques for removal of water contaminants and advances in waste water treatment can be integrated to assess and control water pollution.

\section{REFERENCES}

[1] Roongtanakiat, N., Tangruangkiat, S. and Meesat, R., 2007, Utilization of vetiver grass (Vetiveria zizanioides) for removal of heavy metals from industrial wastewaters., ScienceAsia, 33, 397-403.

[2] Cunningham, S.D., William, R.B. and Jianwei, W.H., 1995, Phytoremediation of contaminated soils., Tibtech, 13, 393-397.

[3] D.A. Hammer, Constructed wetlands for wastewater treatment., 2nd (ed.), Lewis, Chelsea, Michigan, 1989.

[4] Dixon, A., Simon, M. and Burkitt, T., 2003, Assessing the environmental impact of two options for small scale wastewater treatment: Comparing a reed bed and an aerated biological filter using a life cycle approach., Ecol. Eng., 20,
297-308.

[5] Azaizeh, H., Salhani, N., Sebesvari, Z. and Emons, H., 2003, The potential of rhizosphere microbes isolated from a constructed wetland to biomethylate selenium., J. Environ. Qual., 32, 55-62.

[6] Wei, S.H. and Zhou, Q.X., 2004, Discussion on the basic principles and strengthening measures for phytoremediaton of soil contaminated with heavy metals., Chinese. J. Ecol., 23, 65-72.

[7] Xia, H. and Ma, X., 2006, Phytoremediation of ethion by water hyacinth (Eichhornia crassipes) from water., Bioresource Technol., 97, 1050-1054.

[8] Kirkpatrick, A.D., 2005, Assessing constructed wetlands for beneficial use of saline-sodic water., M.S. Thesis, Land Resources and Environmental Sciences, Montana State University, Bozeman.

[9] Lu, Q., 2009, Evaluation of aquatic plants for phytoremediation of eutrophic stormwaters., Ph.D Thesis, University of Florida, Florida.

[10] Stefani, G.D., Tocchetto, D., Salvato, M. and Borin, M., 2011, Performance of a floating treatment wetland for in-stream water amelioration in NE Italy., Hydrobiologia, 674, 157-167.

[11] Singh, O.V., Labana, S., Pandey, G., Budhiraja, R., Jain, R.K., 2003, Phytoremediation: An overview of metallic ion decontamination from soil., Appl. Microbiol. Biotechnol., 61, 405-412.

[12] Jamuna, S. and Noorjah an, C.M., 2009, Treatment of sewage waste water using water hy acinth - Eichhornia sp and its reuse for fish culture., Toxicol. Int., 16(2), 103-106.

[13] Valipour, A., Raman, V.K. and Ghole, V.S., 2011, Phytoremediation of domestic wastewater using Eichhornia crassipes., J. Environ. Sci. Eng., 53(2), 183-190.

[14] Lissy, A.M.P.N, and Madhu, B.Dr.G., 2010, Removal of heavy metals from waste water using water hy acinth., In: Proc. of the International Conference on Advances in Civil Engineering, 42-47.

[15] Dhote, S. and Dixit, S., 2007, Water quality improvement through macrophytes: A case study., Asian J. Exp. Sci., 21(2), 427-430.

[16] Dar, S.H., Kumawat, D.M., Singh, N. and Wani, K.A., 2011, Sewage treatment potential of water hyacinth (Eichhornia crassipes)., Res. J. Environ. Sci., 5(4), 377-385.

[17] Trivedy, R.K. and Pattanshetty, S.M., 2002, Treatment of dairy waste by using water hyacinth., Water Sci. Technol., 45(12), 329-334.

[18] Valipour, A., Raman, V.K. and Motallebi, P., 2010, Application of shallow pond system using water hy acinth for domestic wastewater treatment in the presence of high total dissolved solids (TDS) and heavy metal salts., Environ. Eng. Manage. J., 9(6), 853-860.

[19] Muramoto, S. and Oki, Y., 1983, Removal of some heavy metals from polluted water by water hyacinth (Eichhornia crassipes)., Bull. Environ. Contam. Toxicol., 30, 170-177.

[20] Mahmood, Q., Zheng, P., Islam, E., Hayat, Y., Hassan, M.J., 
Jilani, G. and Jin, R.C., 2005, Lab scale studies on water hy acinth (Eichhornia crassipes marts solms) for biotreatment of textile wastewater., Caspian J. Env. Sci., 3(2), 83-88.

[21] Fonkou, T., Agendia, P., Kengne, I., Akoa, A. and Nya, J., 2002, Potentials of water lettuce (Pistia stratiotes) in domestic sewage treatment with macrophytic lagoon systems in Cameroon., In: Proc. of International Symposium on Environmental Pollution Control and Waste Management, Tunis, 709-714.

[22] Lu, Q., He, Z.L., Graetz, D.A., Stoffella, P.J. and Yang, X., 2010, Phytoremediation to remove nutrients and improve eutrophic stormwaters using water lettuce (Pistia stratiotes L.)., Environ. Sci. Poll. Res., 17, 84-96.

[23] Dipu, S., Kumar, A.A and Thanga, V.S.G., 2011, Phytoremediation of dairy effluent by constructed wetland technology., Environmentalist, 31, 263-278.

[24] Jing, S.R., Lin, Y.F., Wang, T.W. and Lee, D.Y., 2002, Microcosm wetlands for wastewater treatment with different hydraulic loading rates and macrophytes., J. Environ. Qual., 31, 690-696.

[25] Awuah, E., Oppong-Peprah, M., Lubberding, H.J. and Gijzen, H.J., 2004, Comparative performance studies of water lettuce, duckweed and algal-based stabilization ponds using low-strength sewage., J. Toxicol. Environ. Health-Part A., 67(20-22), 1727-1739.

[26] Truong, P. and Baker, D., 1998, Vetiver grass system for environmental protection., Technical Bulletin no. 1998/1, Pacific Rim Vetiver Network, Office of the Royal Development Projects Board, Bangkok, Thailand.

[27] Lakshmana, P.P., Jayashree, S. and Rathinamala, J., 2008, Application of vetiver for water and soil restoration., Available Online: http://www.vetiver.org/TVN/India 1st workshop proceeding//Chapter2-3 pdf.

[28] Girija, N., Pillai, S.S and Koshy, M., 2011, Potential of vetiver for phytoremediation of waste in retting area., The Ecoscan, 1, 267-273.

[29] Mkandawire, M. and Dudel, E.G., 2007, Are lemna spp. effective phytoremediation agents?., Boremediation, Biodiversity Bioavailability, 1(1), 56-71.

[30] Mashauri, D.A., Mulungu, D.M.M. and Abdulhussein, B.S., 2000, Constructed wetland at the university of Dar es salaam., Wat. Res., 34(4), 1135-1144.

[31] Baskar, G., Deeptha, V.T. and Rahman, A.A, 2009, Treatment of wastewater from kitchen in an institution hostel mess using constructed wetland., Int. J. Recent Trends Eng., $1(6), 54-58$.

[32] Wooten, J.W. and Dodd, J.D., 1976, Growth of water hyacinths in treated sewage effluent., Econ. Bot., 30, 29-37.

[33] Schulz, M., Rinle, K., and Kohler, J., 2003, A combined approach of photogrammetrical methods and field studies to determine nutrient retention by submersed macrophytes in running waters., Aquat. Bot., 76(1), 17-29.

[34] T.A. DeBusk and K.R. Reddy, Wastewater treatment using aquatic macrophytes: Contaminant removal processes and management strategies., In: Aquatic Plants for Water Treatment and Resource Recovery, K.R. Reddy and W.H. Smith (eds.), M ongolia publishing Inc., Orlando, 1987.
[35] Brix, H. and Shierup, H.H., 1989, The use of aquatic macrophytes in water pollution control., Ambio, 18, 100-107.

[36] J. Vymazal, H. Brix, P.F. Cooper, R. Haberl, R. Perfler and J. Laber, Removal mechanisms and types of constructed wetlands., In: Constructed Wetlands for Wastewater Treatment in Europe, Vymazal J, Brix H, Cooper PF, Green MB and Haberl, R. (eds), Backhuys Publishers, Leiden, pp. $17-66,1998$

[37] John, R., Ahmad, P., Gadgil, K. and Sharma, S., 2008, Effect of cadmium and lead on growth, biochemical parameters and uptake in Lemna polyrrhiza L., Plant Soil Environ., 54, 262-270.

[38] Maine, M.A., Sune, N.L. and Lagger, S.C., 2004, Chromium bioaccumulation: Comparison of the capacity of two floating aquatic macrophytes., Water Res., 38, 1494-1501.

[39] Mishra, V.K., Upadhyay, A.R., Pandey, S.K. and Tripathi, B.D., 2008a, Concentrations of heavy metals and aquatic macrophytes of Govind Ballabh Pant Sagar an anthropogenic lake affected by coal mining effluent., Environ. Monit. Assess., 141, 49-58.

[40] Ebrahim, A., Ali, M., Gautham, Jawahar, N. and Hariram, S., 2011, A preliminary attempt to reduce total dissolved solids in ground water using different plant parts., Int. J. Pharm. Bio. Sci., 2(2), B414-B422.

[41] Reddy, K.R. and Sutton, D.L., 1984, Water hyacinths for water quality improvement and biomass production., J. Environ. Qual., 13(1), 1-9.

[42] Wolverton, B.C. and McDonald, R.C., 1979a, The water hyacinth: from prolific pest to potential provider., Ambio, 8 , $1-12$.

[43] Aquatics, 2005, PSS 123 Garden Flowers., Online Available: http ://pss.uvm.edu/pss123/aquatics.html

[44] Wilson, J.R., Holst, N. and Rees, M., 2005, Determinants and patterns of population growth in water hy acinth., Aquat. Bot., $81,51-67$.

[45] D.S. Mitchell, The growth and management of Eichhornia crassipes and Salvinia spp. in their native environment and in alien situations., In: Aquatic weeds in southeast Asia, C.K. Varshney and J. Rzoska (eds.), Dr. W. Junk Publisher, The Haque, Netherlands, pp. 167-175, 1976.

[46] Hasan, M.R. and Chakrabarti, R., 2009, Use of algae and aquatic macrophytes as feed in small-scale aquaculture: A review., FAO Fisheries and Aquaculture Technical Paper, pp. 531, Available Online: http://www.fao.org/docrep/012/i1141 e/i1141e04.pdf

[47] Bolenz, S., Omran, H. and Gierschner, K., 1990, Treatments of water hyacinth tissue to obtain useful products., Biol. Waste., 33(4), 263-274.

[48] USEPA, 1988, Design Manual - Constructed wetlands and aquatic systems for municipal wastewater treatment, United States Environmental Protection Agency, Report no. EPA/625/1-88/022, Office of Research and Development, Cincinnati, $\mathrm{OH}, 83$.

[49] APIRIS, 2005, Invasive Non indigenous Plants in Florida., Online Available: http://plants.ifas.ufl.edu/hy acin2.html

[50] Dhote, S. and Dixit, S., 2009, Water quality improvement 
through macrophytes- A review., Environ. Monit. Assess., $152,149-153$.

[51] Patil, J.H., Raj, M.L.A, Bhargav S. and Sowmya S.R., 2011, Anaerobic co-digestion of water hyacinth with primary sludge., Res. J. Chem. Sci., 1 (3), 72-77.

[52] D.S. Mitchell, Surface-floating aquatic macrophytes., In: The Ecology and Management of African Wetland Vegetation, , P. Denny (ed.), Dr. W. Junk Publishers, Dordrecht, pp. 109-124, 1985.

[53] Villamagna, A.M., 2009, Ecological effects of water hy acinth (Eichhornia crassipes) on lake Chapala, Mexico, Ph.D Thesis, Fisheries and Wildlife Sciences, Virginia Polytechnic Institute and State University, Blacksburg, Virginia.

[54] O'Brien, W.J., 1981, Use of aquatic macrophytes for wastewater treatment., Amer. Soc. Civ. Engineers (ASCE), Env. Eng. Div., 107, 681-698.

[55] Center, T.D., Hill, M.P., Cordo, H. and Julien, M.H., 2002 , Water hy acinth., In: Van Driesche, R et al: Biological Control of Invasive Plants in the Eastern United States., USDA Forest Service Publication, FHTET-2002-04, 41-64.

[56] Center, T.D., Van, T.K., Dray, F.A.Jr., Franks, S.J., Rebelo, M.T., Pratt, P.D. and Rayamajhi, M.B., 2005, Herbivory alters competitive interactions between two invasive aquatic plants., Biol. Control, 33, 173-185.

[57] Soli J. Arceivala, Aquatic plant systems, constructed wetlands and vermiculture., In: Wastewater Treatment for Pollution Control 2nd (ed.), Tata McGrawhill Publishing Company Limited, Delhi, 1999.

[58] K.S. Makhanu, 1997, Impact of water hyacinth in Lake Victoria., In: Water and Sanitation for all: Partnerships and Innovations, 23rd Water Engineering and Development Centre Conference, Durban, South Africa.

[59] Bolorunduro, P.L., 2002, Water hyacinth infestation: nuisance or nugget., In: Proc. of the International Conference on Water Hyacinth, National Institute for Freshwater Fisheries Research, New Bussa, Nigeria, pp. 111-121, Online Available:

http://aquaticcommons.org/945/1/WH_111-121.pdf

[60] Zhao, Y.Q., Lu, J.B., Zhu, L. and Fu, Z.H., 2006, Effects of nutrient levels on growth characteristics and competitive ability of water hyacinth (Eichhornia crassipes), an aquatic invasive plant., Biodiversity Science, 14, 159-164.

[61] Reddy, K.R., Sutton, D.L. and Bowes, G., 1983, Freshwater aquatic plant biomass production in Florida., In: Proc. of the Soil and Crop Science Society of Florida, 42, 28-40.

[62] Stephenson, M., Turner, G., Pope, P., Colt, J., Knight, A. and Tchobanoglous, G., 1980, The use and potential of aquatic species for wastewater treatment., Publication no. 65, California State Water Resources Control Board, California.

[63] K.S. Clough, T.A. DeBusk, and K.R. Reddy, Model water hyacinth and pennywort systems for the secondary treatment of domestic wastewater., In: Aquatic Plants for Water Treatment and Resource Recovery, K.R. Reddy and W.H. Smith (ed.), Magnolia Publishing Inc., Orlando, FL, pp. 1031, 1987.

[64] Rodriguez-Gallego, L.R., Mazzeo, N., Gorga, J., Meerhoff, M., Clemente, J., Kruk, C., F.S., Lacerot, G., Garcia, J. and
Quintans, F., 2004, The effects of an artificial wetland dominated by free floating plants on the restoration of a subtropical, hypertrophic lake., Lakes Reservoir., 9, 203-215.

[65] Allen, L.H., Sinclair, T.R. and Bennett, J.M., 1997, Evapotranspiration of vegetation of Florida: Perpetuated misconceptions versus mechanistic processes., In: Proc. of the Soil and Crop Science Society of Florida, 56, 1-10.

[66] El-Gendy, A.S., Biswas, N. and Bewtra, J.K., 2004, Growth of water hy acinth in municipal landfill leachate with different pH., Environ. Technol., 25, 833-840.

[67] Debusk, T.A. and Dierberg, F.E., 1989, Effects of nutrient availability on water hyacinth standing crop and detritus deposition., Hydrobiologia, 174, 151-159.

[68] Moorhead, K.K., Reddy, F.R. and Graetz, D.A., 1988, Water hyacinth productivity and detritus accumulation., Hydrobiologia, 157, 179-185.

[69] Reddy, K.R., Agami, M. and Tucker, J.C., 1989, Influence of nitrogen supply rates on growth and nutrient storage by water hyacinth (Eichhornia crassipes (Mart.) Solms) plants., A

[70] Sato, M. and Kondo, S., 1981, Biomass production of water hyacinth and its ability to remove inorganic minerals from water. I. Effect of the concentration of culture solution on the rates of plant growth and nutrient uptake., Jap. J. Ecol., 31, 257-267.

[71] Reddy, K.R., Agami, M. and Tucker, J.C., 1990, Influence of phosphorus on growth and nutrient storage by water hy acinth (Eichhornia crassipes (Mart.) Solms) plants, Aquat. Bot., 37, 355-365.

[72] Reddy, K.R., Agami, M., D’Angelo, E.M. and Tucker, J.C., 1991, Influence of potassium supply on growth and nutrient storage by water hy acinth., Bioresource Technol., 37, 79-84.

[73] Carignan, R. and Neiff, J.J., 1994, Limitation of water hyacinth by nitrogen in subtropical lakes of the Parana floodplain (Argentina)., Limnol. Oceanogr., 39, 439-443.

[74] Heard, T.A. and Winterton, S.L., 2000, Interactions between nutrient status and weevil herbivory in the biological control of water hyacinth., J. Appl. Ecol., 37, 117-127.

[75] Reddy, K.R., and Tucker, J.C., 1983, Productivity and nutrient uptake of water hyacinth, Eichhornia crassipes I. Effect of nitrogen source., Econ. Bot., 37, 237-247.

[76] Delgado, M., Bigeriego, M., Walter, I. and Guardiola, E., 1994, Optimization of conditions for the growth of water hy acinth in biological treatment., Rev. Int. Contam. Ambient., 10 (2), 63-68.

[77] Reddy, R.R. and Hueston F.M., 1982, Water hyacinth production in sewage effluent., Agricultural Research and Educational Center, University of Florida, Stanford, Florida.

[78] Anghinoni, I. and Barber, S.A., 1980, Phosphorus influx and growth characteristics of corn roots as influenced by P supply., J. Agron., 72, 685-688.

[79] Xie, Y. and Yu, D., 2003, The significance of lateral roots in phosphorus (P) acquisition of water hyacinth (Eichhornia crassipes)., Aquat. Bot., 75, 311-321.

[80] Knipling, E.B., West, S.H. and Haller, W.T., 1970, Growth characteristics, yield potential and nutritive content of water 
hyacinths., In: Proc. of the Soil and Crop Science Society of Florida, 30, 51-63.

[81] Madsen, J.D. and Adams, M.S., 1988, The nutrient dynamics of a submersed macrophyte community in a stream ecosystem dominated by Potamogeton pectinatus. L., J. Freshw. Ecol., 4, 541-550.

[82] Beath, J.M., 2000, Consider phytoremediation for waste site cleanup., Chem. Eng. Progr., 96(7), 61-69.

[83] Allen, R.G., Prueger, J.H. and Hill, R.W., 1992, Evapotranspiration from isolated stands of hydrophytes: Cattail and Bu lrush., Am. Soc. Agric. Eng., 35(4), 1191-1198.

[84] Glenn, E., Thompson, T.L., Frye, R., Riley, J. and Baumgartner, D., 1995, Effects of salinity on growth and evapotranspiration of Typha domingensis Pers., Aquat. Bot., $52,75-91$

[85] Pauliukonis, N. and Schneider, R., 2001, Temporal patterns from lysimeters with three common wetland plant species in the Eastern United States., Aquat. Bot., 71, 35-46.

[86] FNI, 1987, Fishing news international lakes get another cleanup., 26(10), 14-15.

[87] B. Gopal, Water Hyacinth, Aquatic Plant, , Elsevier Science Publishers, B. V. Amsterdam, The Netherlands, pp. 471, 1987.

[88] Yount, J.L. and Crossman, R., 1970, Eutrophication control by plant harvesting., Water Poll. Cont. Fed. J., 42, 173-183.

[89] Wolverton, B.C. and McDonald, R.C., 1979b, Water hy acinth (Eichhornia crassipes) productivity and harvesting studies., Econ. Bot., 33, 1-10.

[90] Jo, J.Y., Ma, J.S. and Kim, I.B., 2002, Comparisons of four commonly used aquatic plants for removing nitrogen nutrients in the intensive bioproduction Korean (IBK) recirculating aquaculture system., Proc. 3rd International Conference on Recirculating Aquaculture, Roanoke, VA, Online Available: http://nsgl.gso.uri.edu/vs gcp/vsgcp c00001/2000/COMPLET E_document.pdf

[91] Sooknah, R.D. and Wilkie, A.C., 2004, Nutrient removal by floating aquatic macrophytes cultured in anaerobically digested flushed dairy manure wastewater., Ecol. Eng., 22, $27-42$

[92] DeBusk, T.A., Williams, L.D. and Ryther, J.H., 1983, Removal of nitrogen and phosphorus from wastewater in a water hyacinth based treatment system., J. Environ. Qual., $12(2), 257-262$

[93] Ayyasamy, P.M., Rajakumar, S., Sathishkumar, M., Swaminathan, K., Shanthi, K., Lakshmanaperumalsamy, P. and Lee, S., 2009, Nitrate removal from synthetic medium and groundwater with aquatic macrophytes., Desalination, $242,286-296$

[94] Snow, A.M. and Ghaly, A.E., 2008, A comparative study of the purification of aquaculture wastewater using water hy acinth, water lettuce and parrot's feather., Am. J. Appl. Sci., 5(4), 440-453.

[95] S.C. Reed, R.W. Crites and E.J. Middlebrooks, Natural systems for water management and treatment., McGraw Hill, New York, 1995.
[96] Richards, J.H. (1982) Development potentials of axillary birds of water hy acinth (Eichhornia crassipes)., Amer. J. Bot., $69,615-622$.

[97] Haller, W.T., Sutton, D.L. and Barlowe, W.C., 1974, Effects of salinity on growth of several aquatic macrophytes., Ecology, 55, 891-894.

[98] Mane, A.V., Saratale, G.D., Karadge, B.A. and Samant, J.S., 2011, Studies on the effects of salinity on growth,polyphenol content and photosynthetic response in Vetiveria zizanioides (L.) Nash., Emir. J. Food Agric., 23(1), 59-70.

[99] Mandi, L., 1994, Marrakesh wastewater purification experiment using vascular aquatic plants Eichhornia crassipes and Lemna gibba., Water Sci. Technol., 29, 283- 287.

[100] S.A. Abbasi, Weeds of despair and hope, In: Wetlands of India, S.A. Abbasi et al., (ed.), Vol. III, New Delhi, Discovery Publishing House, 12-21, 1998.

[101] Adeniran, E., 2011, The efficiency of water hyacinth (Eichornia crassipes) in the treatment of domestic sewage in an African University, Annual Water Resources Conference, lbuquerque, New Mexico.

[102] Chua, H., 1998, Bio-accumulation of environmental residues of rare earth elements in aquatic flora Eichhornia crassipes (Mart.) solms in Guangdong province of China., Sci. Total Environ., 214, 79-85.

[103] De Casabianca, M.L. and Laugier, T., 1995, Eichhornia crassipes production on petroliferous wastewaters: Effects of salinity., Bioresource Technol., 54, 39-43.

[104] Maine, M.A., Duarte, M.V. and Sune, N.L., 2001, Cadmium uptake by floating macrophytes., Water Res., 35(11) 2629-2634.

[105] So, L.M., Chu, L.M. and Wong, P.K., 2003, Microbial enhancement of $\mathrm{Cu} 2+$ removal capacity of Eichhornia crassipes (Mart.)., Chemosphere, 52, 1499-1503.

[106] Delgado, M., Guardiola, E. and Bigeriego. M., 1995, Organic and inorganic nutrients removal from pig slurry by water hyacinth., J. Environ. Sci. Health A., 30, 1423-1434.

[107] Yahya M.N., 1990, The absorption of metal ions by Eichhornia crassipes., Chem. Speciation Bioavailability, 2, 82- 91.

[108] Vesk, P.A., Nockold, C.E. and Aaway, W.G., 1999, Metal localization in water hyacinth roots from an urban wetland., Plant Cell Environ., 22, 149-158.

[109] Soltan, M.E. and Rashed, M.N., 2003, Laboratory study on the survival of water hyacinth under several conditions of heavy metal concentrations., Adv. Environ Res., 7, 82- 91.

[110] Zhu, Y.L., Zayed, A.M., Qian, J.H., Souza, M. and Terry, N., 1999, Phytoaccumulation of trace elements by wetland plants, II. Water hyacinth., J. Environ. Qual. 28, 339-344.

[111] Mishra, V.K., Upadhyay, A.R., Pandey, S.K. and Tripathi, B.D., 2008b, Heavy metal pollution induced due to coal mining effluent on surrounding aquatic ecosystem and its management through naturally occurring aquatic macrophytes., Bioresource Technol., 99, 930-936.

[112] Falbo, M.B. and Weaks. T.E., 1990, A comparison of Eichhornia crassipes (Pontederiaceae) and Sphagnum 
quinquefarium (Sphagnaceae) in treatment of acid mine water., Econ. Bot., 44, 40-49.

[113] Pinto, C.L., Caconia, A. and Souza. M., 1987, Utilization of water hyacinth for removal and recovery of silver from industrial wastewater., pp. 89-102, In: The Use of Macrophytes in Water Pollution Controls.D, Athie (ed.), Water Sci. Technol., 19.

[114] Ho, Y.B. and Wong, W., 1994, Growth and macronutrient removal of water hyacinth in a small secondary sewage treatment plant., Resour. Conserv. Recy., 11, 161-178.

[115] Cossu, R., Haarstad, K., Lavagnolo, M.C. and Littarru, P., 2001, Removal of municipal solid waste COD and NH4-N by phyto-reduction: A laboratory-scale comparison of terrestrial and aquatic species at different organic loads., Ecol. Eng., 16, $459-470$.

[116] Middlebrooks, E.J., 1995, Upgrading pond effluents: An overview., Water Sci. Technol., 31, 353-368.

[117] Giraldo, E. and Garzon, A., 2002, The potential for water hyacinth to improve the quality of Bogota river water in the Muna Reservoir: Comparison with the performance of waste stabilization ponds., Water Sci. Technol., 42, 103-110.

[118] Borges, A.K.P., Tauk-Tornisielo, S.M., Domingos, R.N. and Angelis, D.F., 2008, Performance of the constructed wetland system for the treatment of water from the Corumbatai river., Braz. Arch. Biol. Technol., 51(6), 1279-1286.

[119] Reddy, K.R., 1981, Diel variations in physio-chemical parameters of water in selected aquatic systems., Hydrobiologia, 85(3), 201-207.

[120] Shah, R.A., Kumawat, D.M., Singh, N. and Wani, K.A., 2010, Water hyacinth (Eichhornia crassipes) as a remediation tool for dye-effluent pollution., Int. J. Sci. Nature, 1(2), 172-178.

[121] Mangas-Ramirez, E. and Elias-Gutierrez, M., 2004, Effect of mechan ical removal of water hy acinth (Eichhornia crassipes) on the water quality and biological communities in a Mexican reservoir., J. Aquat. Ecosys. Health Manage., 7, 161-168.

[122] Perna, C. and Burrows, D., 2005, Improved dissolved oxy gen status following removal of exotic weed mats in important fish habitat lagoons of the tropical Burdekin river floodplain, Australia., Marine Poll. Bull., 51, 138-148.

[123] Sooknah, R., 2000, A review of the mechanisms of pollutant removal in water hyacinth systems., Sci. Tech. Res. J., 6, 49-57.

[124] Lehn, H. and Bopp, M., 1987, Prediction of heavy- metal concentrations in mature plants by chemical analysis of seedlings., Plant Soil, 101, 9-14.

[125] EL-Leboudi, A.E, Abd-Elmoniem, E.M., Soliman, E.M. and El-Sayed, O.F., 2008, Removal of some heavy metals from treated waste water by aquatic plants., In: 3rd International Conference on Water Resources and Arid Environments and the 1st Arab Water Forum, Riyadh, Saudi Arabia.

[126] Gamage, N.S. and Yapa, P.A.J., 2001, Use of water hyacinth[Eichhornia crassipes (Mart) solms] in treatment systems for textile mill effluents - A case study., J. Natn. Sci. Foundation Sri Lanka, 29(1\&2), 15-28.

[127] Kulatillake, N. and Yapa, P.A.J., 1984, A study on the use of water hy acinth in rubber effluent treatment systems, In: Proc. of the Malaysian Chemical Congress, Kuala Lumpur,
Malaysia.

[128] Koottatep, T. and Polprasert, C., 1997, Role of plant uptake on nitrogen removal in constructed wetlands located in the tropics., Water Sci. Technol., 36, 1-8.

[129] Jing, S.R., Lin, Y.F., Lee, D.Y. and Wang, T.W., 2001, Nutrient removal from polluted river water by using constructed wetlands., Bioresource Technol., 76, 131-135.

[130] Mohamad, P.M.B.E., 2008, Removal of cadmium from aqueous solution by dried water hyacinth (Eichhornia crassipes)., B.E. Thesis, Chemical and Natural Resources Engineering, Universiti Malaysia Pahang, Malaysia.

[131] Elias, J.M., Salati, F.E. and Salati, E., 2001, Performance of constructed wetland system for public water supply., Water Sci. Techol., 44, 579-584.

[132] Schulz, C., Gelbrecht, J. and Rennert, B., 2004, Constructed wetlands with free water surface for treatment of aquaculture effluents., J. Appl. Ichthyol., 20, 64-70.

[133] Cornwell, D.A., Zoltek, J. and Patrinely, C.D., 1977, Nutrient removal by water hyacinths., J. Water Poll. Control Fed., $57-65$.

[134] Ingersoll, T. and Baker, L.A., 1998, Nitrate removal in wetland microcosms., Water Res., 32, 677-684.

[135] Reddy, K.R., Campbell, K.L., Graetz, D.A. and Portier, K.M.,1982, Use of biological filters for treating agricultural drainage effluents., J. Environ. Qual., 11, 591-595.

[136] Sheffield, C.W., 1967, Water hyacinth for nutrient removal., Hyacinth Cont. J., 27-30.

[137] Ornes, W.H., and Sutton, D.L., 1975, Removal of phosphorus from static sewage effluent by water hy acinth., Hyacinth Cont. J., 13, 56-61.

[138] Bramwell, S.A. and Devi Prasad, P.V., 1995, Performance of a small aquatic plant wastewater treatment system under Caribbean conditions., J. Environ. Manage., 44, 213-220.

[139] Rogers, H.H. and Davis, D.E., 1972, Nutrient removal by water hy acinth., Weed Sci., 20, 423- 428.

[140]Eaton, F.M., 1941, Water uptake and root growth as influenced by inequalities in the concentration of the substrate., Plant Phy siol., 16, 545-564.

[141] John, C.K., 1985, Treatment of argo-industrial wastes using water hy acinth., Water Sci. Technol., 17(4-5), 781-790.

[142] O'Keefe, D.H, Hardy, J.K. and Rao, R.A., 1984, Cadmium uptake by water hy acinth: Effect of solution factors., Environ. Pollut., Series A, 133-147.

[143] Mishra, V.K. and Tripathi, B.D., 2008, Concurrent removal and accumulation of heavy metals by the three aquatic macrophytes., Bioresource Technol., 99, 7091-7097.

[144] Haider, S.Z., Malik, K.M.A., Rahman, M.N. and Wadsten, T., 1984, Proc. Int. Conf. on Water Hy acinth (UNEP, Nairobi) pp. 351.

[145] Chigbo, F.E., Smith, R.W. and Shore, F.L., 1982, Uptake of arsenic, cadmium, lead and mercury from polluted waters by the water hy acinth., Environ. Poll., A27, 31-36.

[146] Liao, S.W. and Chang, W.L., 2004, Heavy metal phytoremediation by water hyacinth at constructed wetlands 
in Taiwan., J. Aquat. Plant Manage., 42, 60-68.

[147] Wang, Q., Cui, Y. and Dong, Y., 2002, Phytoremediation of polluted waters: Potentials and prospects of wetland plants., Acta Biotechnol., 22,199-208.

[148] Zayed, A., Gowthaman, S. and Terry, N., 1998, Phytoaccumulation of trace elements by wetland plants: I. Duckweed., J. Environ. Qual., 27, 715-721.

[149] Greenfield, B.K., Siemering, G.S., Andrews, J.C., Rajan, M., Andrews, S.P. and Spencer, D.F., 2007, Mechanical shredding of water hyacinth (Eichhornia crassipes): Effects on water quality in the Sacramento-San Joaquin river delta, California., Estuar. Coast., 30, 627-640.

[150] Chandra, P. and Kulshreshtha, K., 2004, Chromium accumulation and toxicity in aquatic vascular plants., Bot. Rev., 70(3), 313-327.

[151] K. Lindsey and H.M. Hirt, Use water hyacinth! A Practical Handbook of uses for the Water Hyacinth from Across the World, Anamed: Winn enden, 114, 1999.

[152] Singhal, V. and Rai, J.P.N., 2003, Biogas production from water hyacinth and channel grass used for phytoremediation of industrial effluents., Bioresource Technol., 86, 221-225.

[153] C.D. Sculthorpe, The biology of aquatic vascular plants., Arnold, London, pp. 610, 1967.

[154] D.S. Mitchell, Aquatic weeds in Australian inland waters., Australian Government Publishing Service, pp. 189, 1978.

[155] A.E. Williams and R.E. Hecky, Invasive aquatic weeds and eutrophication: The case of water hyacinth in lake Victoria., In: Restoration and Management of Tropical Eutrophic Lakes, M.Vikram Reddy (ed.), Science Publishers, Enfield, NH, USA, pp. 187-225, 2005.

[156] Kasselmann, C., 1995, Aquarienpflanzen., Egen Ulmer GMBH \& Co, Stuttgart, pp. 472 (in German).

[157] Aoi, T. and Ohba, E., 1995, Rates of nutrient removal and growth of the water lettuce (Pistia stratiotes)., In: Proc. of the 6th International Conference on the Conservation and Management of Lakes Kasumigaura.

[158] Karpiscak, M.M., Foster, K.E., Hopf, S.B., Bancroft, J.M. and Warshall, P.J., 1994, Using water hyacinth to treat municipal wastewater in the desert southwest., Water Resour. Bull., 30, 219-227.

[159] El-Gendy, A.S., Biswas, N. and Bewtra, J.K., 2005, A floating aquatic system employing water hyacinth for municipal landfill leachate treatment: Effect of leachate characteristics on the plant growth., J. Environ. En g. Sci., 4(4), 227-240.

[160] Reddy, K.R. and Debusk, W.F., 1985, Nutrient removal potential of selected aquatic macrophytes., J. Environ. Qual., $14,459-462$.

[161] Aoi, T. and Hayashi, T., 1996, Nutrient removal by water lettuce (Pistia stratiotes)., Water Sci. Technol., 34(7-8), 407-412.

[162] Sridhar, M.K.C., 1986, Trace element composition of Pistia stratiotes in a polluted lake in Nigeria., Hydrobiologia, 131, 273-276.

[163] Sen, A.K., Mondal, N.G. and Mondal, S., 1987, Studies of uptake and toxic effects of $\mathrm{Cr}$ (VI) on Pistia stratiotes., Water Sci. Technol., 7, 119-127.

[164] Gumbricht, T., 1993, Nutrient removal processes in freshwater submersed macrophyte systems., Ecol. Eng., 2, $1-30$.

[165] Reddy, K.R., 1983, Fate of nitrogen and phosphorus in a waste-water retention reservoir containing aquatic macrophytes., J. Environ. Qual., 12(1), 137-141.

[166] Lu, Q., He, Z.L., Graetz, D.A., Stoffella, P.J. and Yang, X., 2011, Uptake and distribution of metals by water lettuce (Pistia stratiotes L.)., Environ. Sci. Poll. Res., 18, 978-986.

[167] Mukhopadhyay, S., Manna, N. and Mukherjee, S., 2007, A laboratory scale study of phytoremediation of arsenic by aquatic plant (water lettuce)., In: Proc. International Conference on Cleaner Technologies and Environmental Management, PEC, Pondicherry, India, pp. 366-371.

[168] Alam, B., Chatterjee, A.K. and Dattagupta, S., 1995, Bio accumulation of Cd (I) by water lettuce (Pistia stratioles L.)., Poll. Research, 14 (1), 59-64.

[169] De, A.K., Sen, A.K., Modak, D.P. and Jana, S., 1985, Studies on toxic effects of $\mathrm{Hg}$ (II) on Pistia stratioles L., Water Air Soil Poll., 24(3), 351-360.

[170] Mishra,V.K., Trip athi B.D. and Kim, K., 2009, Removal and accumulation of mercury by aquatic macrophytes from an open cast coal mine effluent., J. Hazard. Mater., 172, 749-754.

[171] Mishra, V.K. and Tripathi, B.D., 2009, Accumulation of chromium and zinc from aqueous solutions using water hyacinth (Eichhornia crassipes)., J. Hazard. Mater., 164, 1059-1063.

[172] Skinner, K., Wright, N. and Porter-Goff, E., 2007, Mercury uptake and accumulation by four species of aquatic plants., Environ. Pollut., 145, 234-237.

[173] Calderon, I.M., 2010, Green movement against green water., Honors Thesis, College of Agriculture and Life Sciences, Landscape Architecture of Cornell University, USA.

[174] Truong, P., 1999, Vetiver grass technology for land stabilisation, erosion and sediment control in the Asia Pacific region., In: Proc. of the 1st Asia Pacific Conference on Ground and Water Bioengineering for Erosion Control and Slope Stabilisation, Manila, Philippines.

[175] Truong, P., Carlin, G., Cook, F. and Thomas, E., 2003, Vetiver grass hedges for water quality improvement in acid sulfate soils, Queensland, Australia., In: Proc. of the 3rd International Conference on Vetiver and Exhibition, Guangzhou, China.

[176] Dulton, P.A., Smith, R.J. and Truong, P.N.V., 1996, Vetiver grass hedges for erosion control on cropped flood plain: Hedge hydraulics., Agr.Water Manage., 31, 91-104.

[177] Truong, P. and Stone, R., 1996, Vetiver grass for landfill rehabilitation: Erosion and leachate control., Report to DNR and Redland Shire Council, Queensland, Australia.

[178] M. Maffei, Vetiveria: The genus Vetiveria., CRC Press, Boca Raton, 2002.

[179] Vieritz, A., Truong, P., Gardner, T. and Smeal, C., 2003, Modelling Monto Vetiver growth and nutrient uptake for 
effluent irrigation schemes., In: Proc. of the 3rd International Vetiver Conference, Guangzhou, China.

[180] Zhang, X.B., 1992, Vetiver grass in P.R. China - Presented at the vetiver workshop., Vetiver Newsletter, 8, 8-10.

[181] Truong, P.N., 2000, The global impact of vetiver grass technology on the environment., In: Proc. of the 2nd International Conference on Vetiver, Office of the Royal Development Projects Board, Bangkok, Thailand, 48-61.

[182] Xia, H., Liu, S. and Ao, H., 2000, Study on purification and uptake of garbage leachate by vetiver grass., In: Proc. of the 2nd International Conference on Vetiver, Thailand.

[183] Zheng, C.R, Tu, C. and Chen, H.M., 1998, A preliminary study on purification of vetiver for eutrophic water., In: Vertiver Research and Development, China Agricultural Science and Technology Press, Beijing, pp. 81-84.

[184] Kong, X., Weiwen, L., Biqing, W. and Fuhe, L., 2003, Study on vetiver's purification from pig farm., In: Proc. of the 3rd International Conference on Vetiver and Exhibition, China, pp. 181-185.

[185] Roongtanakiat, N. and Chairoj, P., 2001a, Uptake potential of some heavy metals by vetiver grass., Kasetsart J. (Nat. Sci.), $35,46-50$.

[186] Roongtanakiat, N. and Chairoj, P., 2001b, Vetiver grass for the remediation of soil contaminated with heavy metals., Kasetsart J. (Nat. Sci.), 35, 433-440.

[187] Roongtanakiat, N., Nirunrach, T., Chanyotha, S. and Hengchavanich, D., 2003, Uptake of heavy metals in landfill leachate by vetiver grass., Kasetsart J. (Nat.Sci.), 37, 168-175.

[188] Xia, H.P. and Shu, W.S., 2001, Resistance to and uptake of heavy metals by Vetiveria zizanioides and Paspalum notatum from lead/zinc mine tailings., Acta Ecol. Sin., 21, 1121-1129.

[189] Jayashree, S., Rathinamala, J. and Lakshmanaperumalsamy, P., 2011, Determination of heavy metal removal efficiency of Chrysopogon zizanioides (vetiver) using textile wastewater contaminated soil., J. Environ. Sci. Technol., 4(5), 543-551.

[190] Truong, P. and Hart, B., 2001, Vetiver grass for wastewater treatment., Pacific Rim Vetiver Network Technical Bulletin No. 2001/2, Available Online: http://www.vetiver.org/PR VN _wastewater_bul.pdf

[191] Stefanie, W., Paul, T., Alison, V. and Cameron, S., 2003, Response of vetiver grass to extreme nitrogen and phosphorus supply., Available Online: http://www.vetiver.com/ICV3-Pr oceedings/AUS_Extreme\%20N\%26P.pdf

[192] Boonsong, K. and Chansiri, M., 2008, Domestic waste water treatment using vetiver grass cultivated with floating platform technique., AU J.T., 12(2), 73-80.

[193] Cull, R.H., Hunter, H., Hunter, M. and Truong, P., 2000, Application of vetiver grass technology in off-site pollution control, (II) Tolerance of vetiver grass towards high levels of herbicides under wetland conditions., In: Proc. of the 2nd Intern, Vetiver Conference, Thailand.

[194] Wagner, S., Truong, P., Vieritz, A. and Smeal, C., 2003, Response of vetiver grass to extreme nitrogen and phosphorus supply., In: Proc. of the 3rd International Conference on Vetiver and Exhibition, Guangzhou, China.

[195] Anon, 1997, A consideration and preliminary test of using vetiver for water eutrophication control in Taihu Lake in China., In: Proc. of the International Vetiver Workshop, Fuzhou, China.

[196] Zheng, C.R., Tu, C., and Chen, H.M., 1997, Preliminary study on purification of eutrophic water with vetiver., In: Proc. of the International Vetiver Workshop, Fuzhou, China. 